\title{
重心検出による随意型移動支援機器の開発
}

\author{
田中 陽平 ${ }^{a}$ 阿部 あすか ${ }^{b}$ 田村 和輝 ${ }^{c}$ 宍戸 道明 $\mathrm{a}^{\text {,* }}$
}

\section{Development of Voluntary Mobile Support Equipment by Centroid Detection}

\author{
Yohei Tanaka ${ }^{\mathrm{a}}$, Asuka Abe ${ }^{\mathrm{b}}$, Kazuki Tamura ${ }^{\mathrm{c}}$, Michiaki Shishido ${ }^{\mathrm{a},{ }^{*}}$
}

(Received March 14, 2019; revised April 24, 2019; accepted May 20, 2019)

\begin{abstract}
In recent years, an increasing number of care recipients and a shortage of caregivers, by acceleration of declining birthrate and aging, are getting worse. From such social background, the application of the mechatronics technology was expected to reduce the burden on caregivers and the independence of the people requiring nursing care. Therefore, omni-directional moving system that operates intuitively by moving the centroid was developed by this research group. In this study, evaluated, the transient response characteristics and centroid acquisition accuracy of the centroid detection-type movement equipment were evaluated. In addition, the cancellation condition of the boarding standby state for safe boarding was considered. Assuming a load of $60 \mathrm{~kg}$ on this equipment, the servo system can be accurately controlled in the range of 2538 to $6345 \mathrm{rpm}$. At $60 \mathrm{~kg}$ load condition, the maximum error distance was only $49 \mathrm{~mm}$. Therefore, the omni-directional mobile system can operate accurately. As the cancellation condition of the boarding standby state, the rest time is necessary to set to $2 \mathrm{sec}$ or more. Moreover, when targeting senior citizens which have low dynamic balance, the rest time is necessary to set still time longer.
\end{abstract}

キーワード：介護ロボット，直感的操作，重心検出，全方向移動

Keywords : Care-robots, Intuitive operation, Centroid detection, Omni-directional.

\section{1. 緒言}

昨今の日本社会では, 少子高齢化の加速による被介護 者の増加および介護者の不足が深刻化している。被介護 者は，日常生活における身体的動作（随意運動）に制限 を持つ場合が多く，生活の質（Quality of Life: QOL）の維 持・向上の課題が顕在化している。とくに，自立した生 活への障害や自己の存在感・生きがいの喪失などは自殺 に繋がる社会問題となっており，日本の高齢者自殺数は 世界 2 位という高い水準に達している(1)。また，長期的

* Corresponding author. E-mail: m-shishido@tsuruoka-nct.ac.jp

a 鶴岡工業高等専門学校

干997-8511 山形県鶴岡市井岡字沢田 104

National Institute of Technology, Tsuruoka College

104 Sawada, Inooka, Tsuruoka, Yamagata, Japan 997-8511

b 本田技研工業株式会社

干107-8556 東京都港区南青山 2-1-1

Honda Motor Co., Ltd.

2-1-1 Minami-Aoyama, Minato-ku, Tokyo, Japan 107-8556

c 浜松医科大学

干431-3192 静岡県浜松市東区半田山一丁目 20-1

Hamamatsu University School of Medicine

1-20-1 Handayama, Higashi-ku, Hamamatsu, Shizuoka, Japan 431-3192
な介護は介護者を拘束する時間が長く，日常生活への負 担が大きい。とりわけ，介護による精神的および肉体的 ストレスにより健康を害するリスクも高く(2), 職場・職 種によっては自身の仕事と介護の両立が困難となり離職 するケースも多い(3)。

Fig. 1 に要介護認定者数および介護施設数の推移を示 す。要介護認定者数は 10 年間で約 1.4 倍に増加している。 一方, 介護施設数は, 緩やかな増加傾向を示しているに も拘わらず，現在の急速な需要に対する供給が追いつい ていない(4-5)。加えて, 要介護者の中には経済的な理由か ら介護施設に入居できない人も多く, 居宅介護サービス 受給者数は施設サービス受給者数の 4.3 倍となっている (5)。居宅介護を支援するホームヘルパーの需要も高まる 一方で，過酷な労働条件かつ低賃金による人員の供給不 足が課題となっており (2), 高齢者による居宅介護が増加 している(1)。

このような社会的背景を受け，高齢者や身体障害者な どの要介護者を介護するためには，介護技術を応用した メカトロニクス技術が期待されている(6)。しかしながら， 多くの介護ロボットは使用者のニーズに対して操作が複 
Number of people who have certification of long-term care

$\rightarrow-$ Number of the long-term care facilities

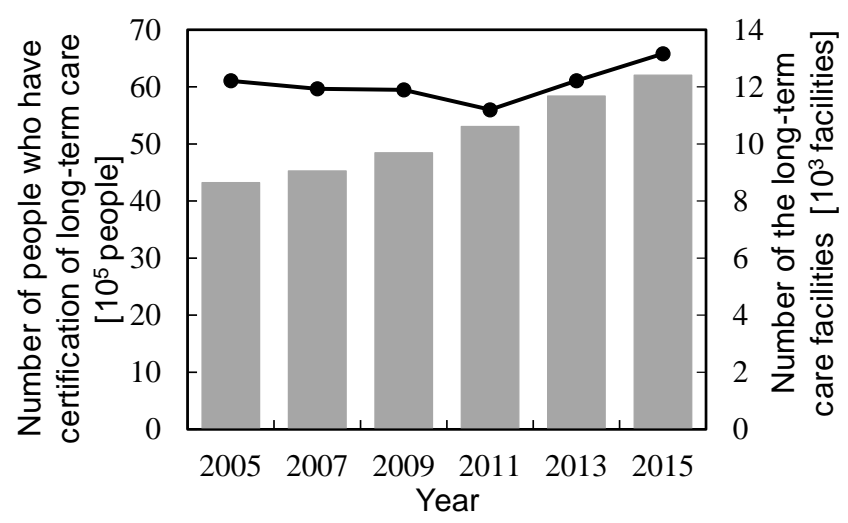

Fig. 1. Transition of the number of people who have certification of long-term care and the number of long-term care facilities.

雑であり, 機器の操作には長時間の操作訓練が必要とな る。加えて, 介護現場で働く介護者からロボット開発者 へのフィードバックは困難である。すなわち，自立支援 と介護負担の軽減を図り, 被介護者および介護者の QOL 向上に資する改善を図るためには，ユーザビリティの高 い介護ロボット開発が不可欠となる。とりわけ，被介護 者の移動性向上による主体的な活動の促進は, 寝たきり 状態の予防や身体機能の維持 - 回復によって, 生活不活 発病の発病リスク軽減が期待される。

そこで本研究グループでは, 移動用介護ロボットに着 目し，搭乗者の体重移動のみを入力信号とした直感的随 意操作を可能とする全方向移動システムを開発した。本 システムは, 負荷荷重から重心位置を検出して自動的に 移動方向を指定するため, 搭乗者には複雑な操作が伴わ ない。本機器の使用によって被介護者の主体的な活動を 促進し，介護者の負荷軽減を実現することで，両者の QOL 向上が期待される。また, 機器操作には特別なコン トローラを用いないことから, 両手の自由な状態を維持 しつつ，誤操作による意図しない駆動の抑制が可能であ る。

本研究では，全方向移動システムを実装した重心検知 式移動機器の移動支援機器への利用を目指し, 過渡応答 特性と重心取得精度を評価した。

\section{2. 重心検知式移動機器}

Fig. 2 に重心検知式移動機器の概観を示す。本機器は 後述する全方向移動システムを搭載しており，搭乗者は 機器上面にある円盤状の座面に着座した操縦者の体重移 動によって操作される。機器寸法は $540(w) \times 540(d) \times$ $210(t) \mathrm{mm}$ であり, 搭乗部の円盤は直径 $540 \mathrm{~mm}$ である。

Fig. 3 に重心検知式移動機器の構成を示す。本機器は

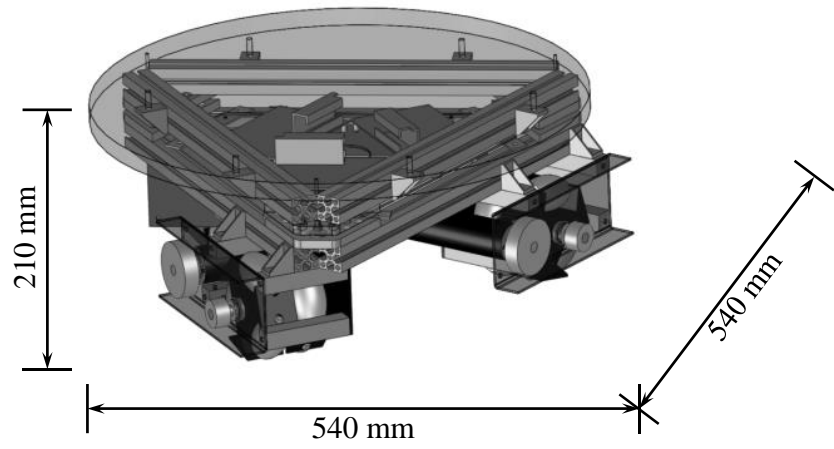

Fig. 2. Overview of the centroid detection-type movement equipment.

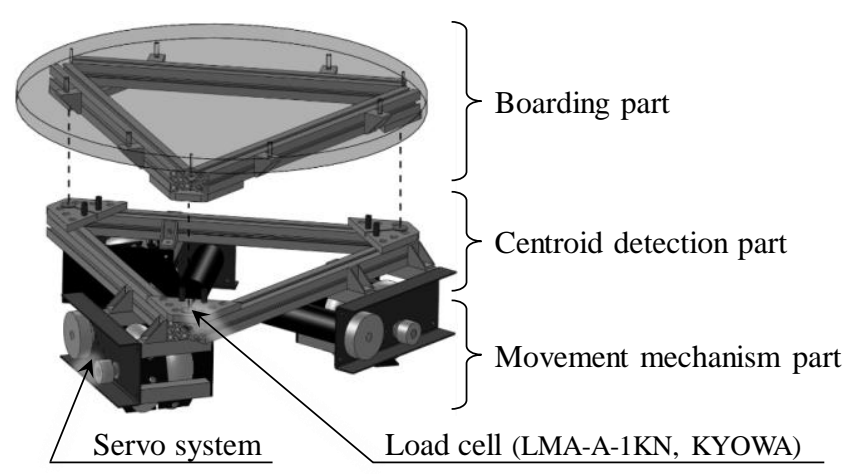

Fig. 3. Structure of the centroid detection-type movement equipment.

上部から「搭乗部」,「重心取得部」および「移動機構部」 にて構成される。重心取得部には 2 つ正三角形フレー ムが設置され，その各頂点にロードセル（LMA-A-1KN， KYOWA）が挟まれて設置されている。1点に $90 \mathrm{~kg}$ の負 荷が集中することを考慮し, 定格容量 $1 \mathrm{kN}$ のロードセ ルを使用した。フレーム下部の移動機構部には，全方向 移動を可能とするオムニホイールを用いた 3 つのサーボ システムを搭載している。

\section{1 全方向移動システム}

本システムは，重心検知式移動機器における搭乗部の 円盤に搭乗した操縦者の重心位置から移動ベクトルを算 出し, 移動機構部を駆動させて任意の指示方向への移動 を実現する。

Fig. 4 に全方向移動システムの動作フローを示す。ま ず，システム起動直後にロードセルのキャリブレーショ ンが開始される。キャリブレーションが完了するとシス テムは操縦者の搭乗待機状態に移行する。操縦者が機器 に搭乗すると, 各ロードセルの測定值から重心を算出し, 駆動閾值の条件を満たしたとき駆動する。操縦者が機器 から降りると, システムは再び操縦者の搭乗待機状態に 移行する。 


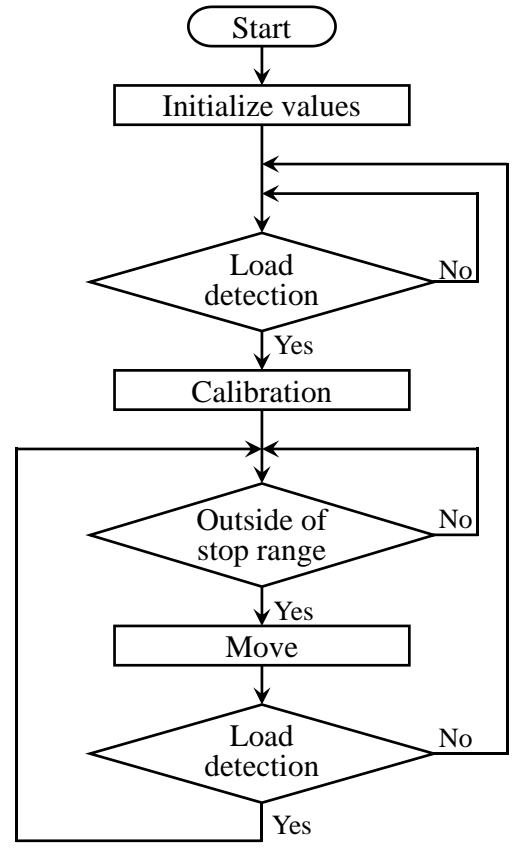

Fig. 4. Movement flow of omni-directional moving system.

\section{2 サーボシステム}

重心検知式移動機器の移動機構部は, DC モータを搭 載した 3 セットのサーボシステムにより構成されている。 そのため, 任意な 3 自由度の速度を発生できるホロノミ ック性と, あらゆる方向に移動・旋回可能な全方向性を 有したホロノミック全方向移動(7)を実現する。

Fig. 5 にサーボシステムの概観を示す。サーボシステ ムは，回転数と回転方向の信号を入力信号としてアクチ ユエータをフィードバック制御し，指示された速度でタ イヤを回転させる。アクチュエータには, バッテリによ る駆動を考慮して DC モータ（RE40，MAXON）を採用 した。また，ホロノミック全方向移動を実現するため, 移動用ホイールにはホイール円周上に自由に回転する樽 型車輪を有したオムニホイール（TYPE2530-4HXU, FUJI MFG）を採用した。

Fig. 6 にサーボシステムの概要を示す。図中の破線部 は, DC モータ駆動用の強電 $(24 \mathrm{~V})$ 回路を示し, それ以 外は弱電 $(5 \mathrm{~V})$ 回路である。各サーボシステムの制御装 置は独立しており，システムを制御するマイクロコンピ ュータ (ATmega328, Atmel Corporation)（以下，マイコ ン）は，1 組のシステムに対して 1 個ずつ搭載されてい る。

Table 1 に本機器に使用するバッテリの仕様を示す。3 個の DC モータを同時に駆動させるには，30 A の電源供 給が必要となる。また, 機器への搭載を考慮して小型化・ 軽量化を図るため，バッテリにはリチウムポリマーバッ テリーを使用した ${ }^{(8)}$ 。強電回路には直列に接続した 2 個

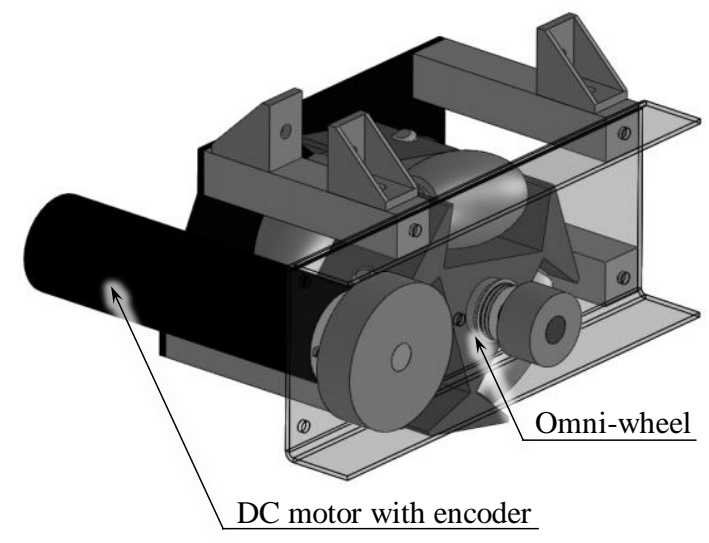

Fig. 5. Overview of the servo system.

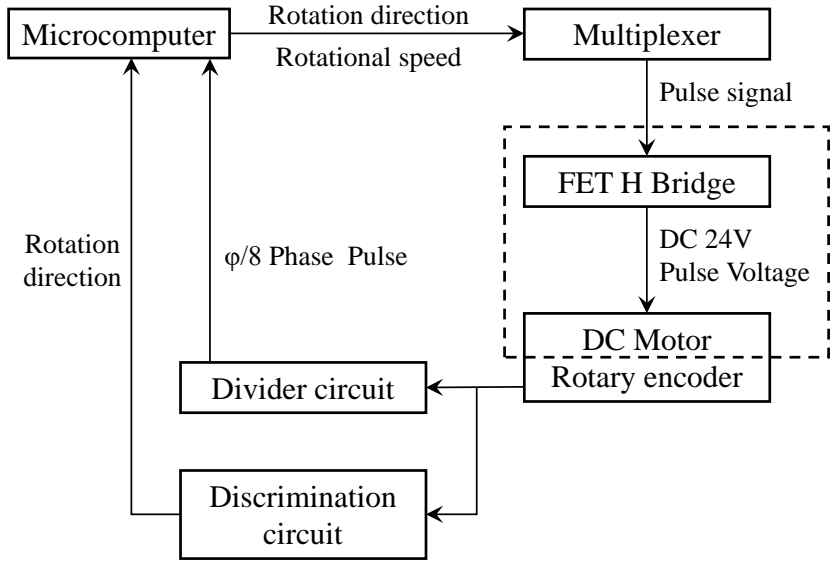

Fig. 6. Outline of the servo system.

Table 1. Specification of battery used for this equipment.

\begin{tabular}{cc|cc}
\hline & & High voltage & Low voltage \\
\hline Maker & & enRoute & IP \\
Model & & enLipo & LiPo Flight Pack \\
Rated voltage & {$[\mathrm{V}]$} & 11.1 & 11.1 \\
Rated capacity & {$[\mathrm{mAh}]$} & 1800 & 850 \\
Discharge allowance & {$[\mathrm{C}]$} & 20 & 25 \\
\hline
\end{tabular}

の強電用バッテリ，弱電回路には 1 個の弱電用バッテリ を使用した。

\section{3 重心位置算出}

重心位置は, 重心検知式移動機器の重心算出部におけ るロードセルの測定值から算出した。

Fig. 7 に重心位置算出に用いるパラメータを示す。正 三角形は機器の三角形フレームを表し, ロードセルは三 角形の各頂点に設置されている。ロードセルの出力信号 は，計装アンプ（AD623, Analog Devices, Inc.）にて増幅 され, マイコンの $\mathrm{A} / \mathrm{D}$ 変換によってデジタル信号 $F_{i}$ に変 


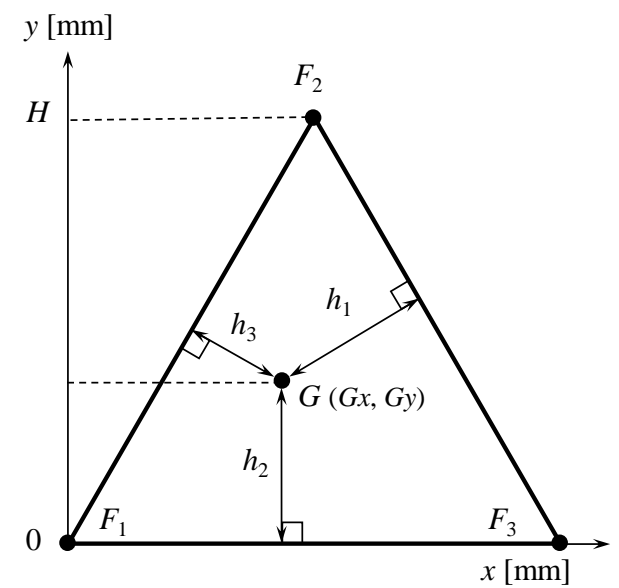

Fig. 7. Parameters used for calculating the centroid position.

換される。3 点のロードセルにかかる荷重をそれぞれ $F_{1}$, $F_{2}, F_{3}$, 操縦者の総質量を $m$, 重心を $G$, 正三角形の各 辺に対する垂線の長さをそれぞれ $h_{1}, h_{2}, h_{3}$ とする。こ のとき, $F_{i}$ と $h_{i}$ の関係を以下に示す。

$$
m g h_{i}=F_{i} H
$$

ここで, $m g$ は操縦者の総重量であり $, F_{1}, F_{2}, F_{3}$ の合計 から求められる。

$$
m g=F_{1}+F_{2}+F_{3}=\sum_{i=1}^{3} F_{i}
$$

式(1), 式(2)より, 各荷重と総重量から $h$ が算出される。

$$
h_{i}=\frac{F_{i}}{\sum_{k=1}^{3} F_{k}} H
$$

ここで, 重心座標を求めるため, $F_{1}$ を原点とした $x y$ 座標 を考える。重心の $x$ 座標を $G x, y$ 座標を $G y$ としたとき，

$$
\begin{aligned}
G x\left(\begin{array}{l}
1 \\
0
\end{array}\right)+ & h_{2}\left(\begin{array}{l}
0 \\
1
\end{array}\right) \\
& =G y\left(\begin{array}{l}
\cos (\pi / 3) \\
\sin (\pi / 3)
\end{array}\right)+h_{3}\left(\begin{array}{c}
\cos (-\pi / 6) \\
\sin (-\pi / 6)
\end{array}\right)
\end{aligned}
$$

となり，各值を代入すると，

$$
G x=\sqrt{3} \frac{h_{2}+2 h_{3}}{3}
$$

となる。以上より，重心座標は次式で示される。

$$
G\left(\sqrt{3} \frac{h_{2}+2 h_{3}}{3}, h_{2}\right)
$$

\section{3. 実験方法}

\section{1 過渡応答特性評価}

重心検知式移動機器の移動機構部であるサーボシステ ムについて, DCモータの回転数を経時的に記録し，任意 の荷重負荷による過渡応答特性を評価した。

DC モータの回転数は，サーボシステムに速度指令を ステップ入力したときのエンコーダパルスから算出した。

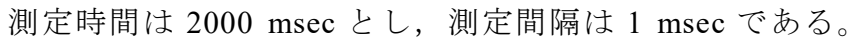
サーボシステムへの速度指令は, 正回転 64 ステップ （0 63）と逆回転 64 ステップ（0 -63）に区分される。 DC モータの最大回転数は $8000 \mathrm{rpm}$ であり, 1 ステップ は $8000 / 63 \fallingdotseq 126.9 \mathrm{rpm}$ である。指定する速度指令は, “10” $(10 \times 126.9=1269 \mathrm{rpm})$ から“60” $(60 \times 126.9=7614 \mathrm{rpm})$ の 10 ステップ間隔とし, 各速度指令における正回転の回 転数を測定した。荷重の負荷条件は, 無負荷状態と負荷 状態の 2 種類とした。無負荷状態はオムニホイールを地 面から離すアイドル状態, 負荷状態はシステム上に $60 \mathrm{~kg}$ の操縦者を搭乗させた状態とした。

\section{2 重心取得精度評価}

重心検知式移動機器に重心取得精度測定用荷重（2 kg: 水で満たしたペットボトル， $60 \mathrm{~kg}$ ：人）を負荷し，負荷 位置座標と重心算出部により算出される重心位置座標の 関係から，全方向移動システムの重心取得精度を評価し た。

Fig. 8 に重心取得精度測定用マトリックスを示す。図 中の円は搭乗部の円盤, 円内接三角形は機器の三角形フ レームに対応している。円心を重心座標の原点 $(x=0, y=0)$ として,三角形内を $50 \times 50 \mathrm{~mm}^{2}$ のマトリックスに分割し， その各交点を測定点とした。

Fig. 9 に測定装置の概観を示す。各測定点には円柱（材 質：鉄，直径： $42 \mathrm{~mm}$ ，高さ: $63 \mathrm{~mm}$ ）を設置し，その上に 各荷重を負荷した。円柱の重量は各負荷荷重に含まれる。

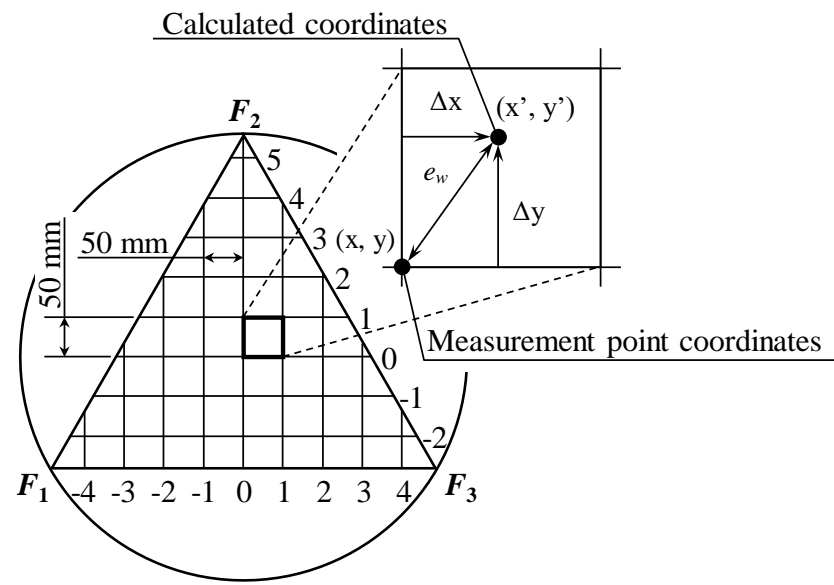

Fig. 8. Matrix for measuring centroid accuracy. 


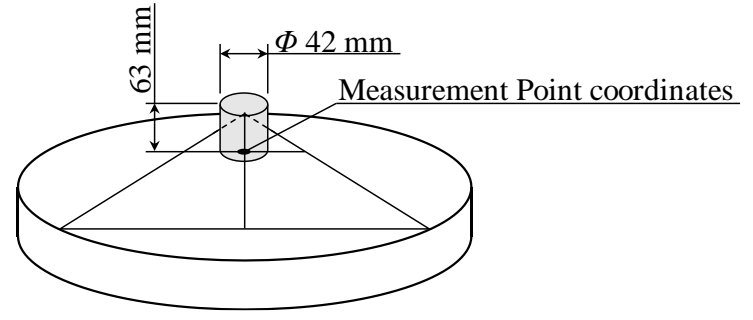

Fig. 9. Overview of measuring equipment.

重心取得精度は, 測定点座標 $(x, y)$ と算出座標 $(x$, $\left.y^{\prime}\right)$ との距離である誤差距離 $e_{w}$ の值によって評価される。 誤差距離の算出式を次式に示す。

$$
e_{w}=\sqrt{\left(x^{\prime}-x\right)^{2}+\left(y^{\prime}-y\right)^{2}}
$$

誤差距離が低值であるほどシステムの重心取得精度は高 精度となる。また，測定点に設置される円柱の半径は 21 $\mathrm{mm}$ であるため, $21 \mathrm{~mm}$ の誤差距離は評価実験上発生す る。

\section{4. 実験結果および考察}

\section{1 過渡応答特性評価}

重心検知式移動機器の移動機構部であるサーボシステ ムについて，無負荷と $60 \mathrm{~kg}$ の荷重を負荷した 2 種類の 負荷条件状態により，システムの過渡応答特性を評価し た。

Fig. 10 に各負荷状態におけるサーボシステムの過渡応 答特性を示す。無負荷状態(a)では，速度指令“60”を除 くすべての速度指令において, オーバーシュートが確認 された。オーバーシュート後, 回転数はハンチングを経 て各速度指令の回転数へ収束した。いかなる回転数にお いても $1500 \mathrm{msec}$ 後に目標の回転数付近で安定した。

負荷状態(b)では，すべての速度指令においてオムニホ イールのスリップが確認され，回転数は目標值付近にて ハンチングした。また，ハンチングが比較的安定した $1500 \mathrm{msec}$ 付近における回転数の高低差は, 最小 $330 \mathrm{rpm}$

(速度指令 “ 60 ” 入力時), 最大 $1540 \mathrm{rpm}$ (速度指令 “ 40 ” 入力時）であった。1500 $\mathrm{msec}$ から $2000 \mathrm{msec}$ の範囲にお いて, 速度指令 “50” 以下における目標回転数と測定值 の差は最大 $190 \mathrm{rpm}$ 程度であり, システムはおおむね追

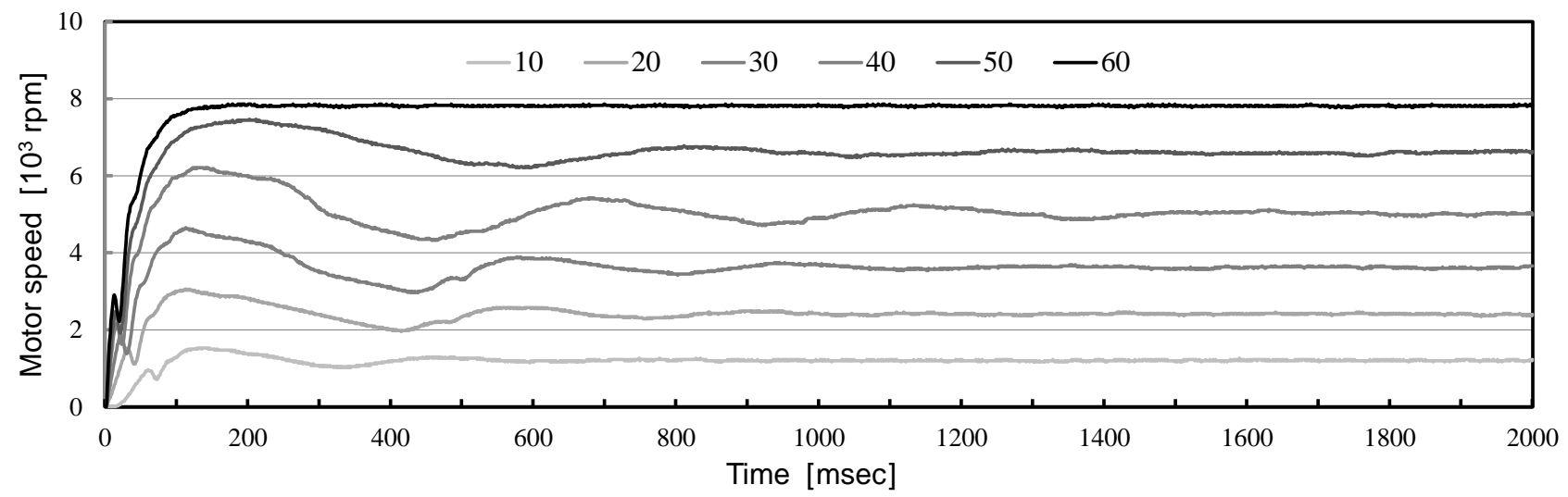

(a) No load condition.

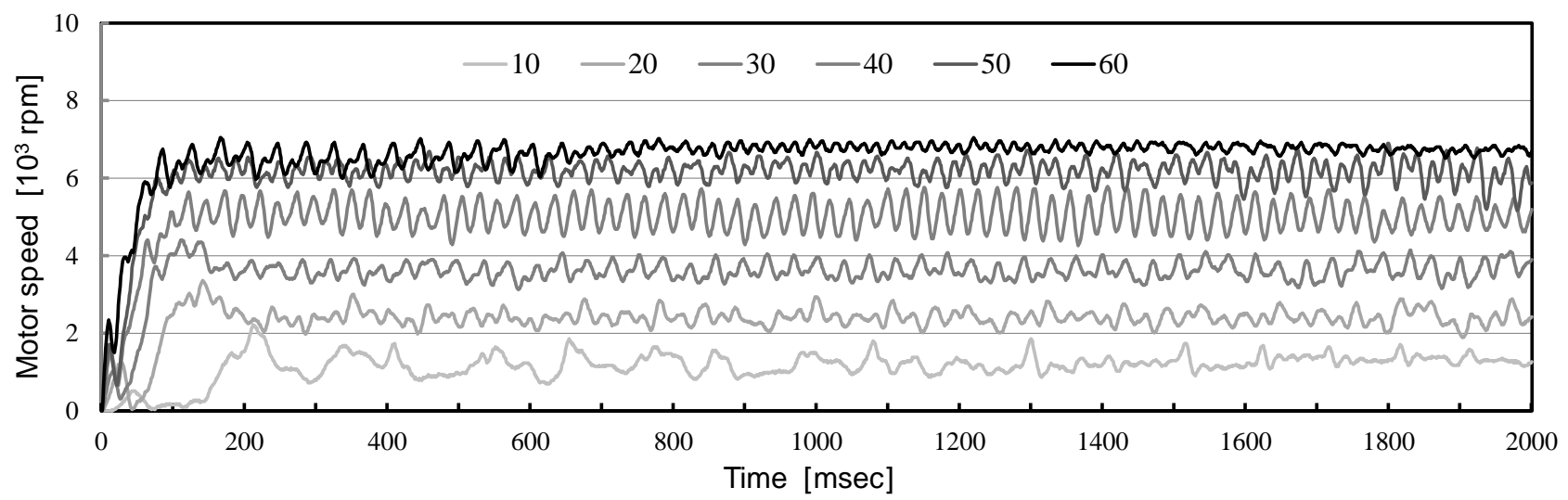

(b) Load condition

Fig. 10. Transient response characteristics of the servo system in each load conditions. 
従している。一方，速度指令 “60”における目標回転数 と測定值の差は約 $850 \mathrm{rpm}$ であり，システムの追従が確 認されなかった。以上の結果より，60 kg の積載物を想定 した場合，システムは速度指令 “50”，才なわち $6345 \mathrm{rpm}$ 以下において正確に制御することが可能である。

Fig. 11 に各負荷状態における立ち上がり時間と速度指 令の関係を示す。ここで，立ち上がり時間は，速度指令 による目標值の $10 \%$ か 90\%に達するまでの経過時間で ある。無負荷状態では, 各速度指令においておおむねフ ラットな特性を示している。一方，負荷状態における立 ち上がり時間は, 各速度指令に対するばらつきが大きく, 無負荷状態と比較して遅い傾向を示した。とくに，速度

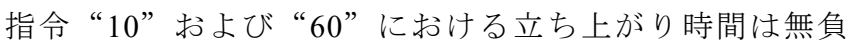
荷状態の 3 4 倍であり,グラフはバスタブ曲線を示した。

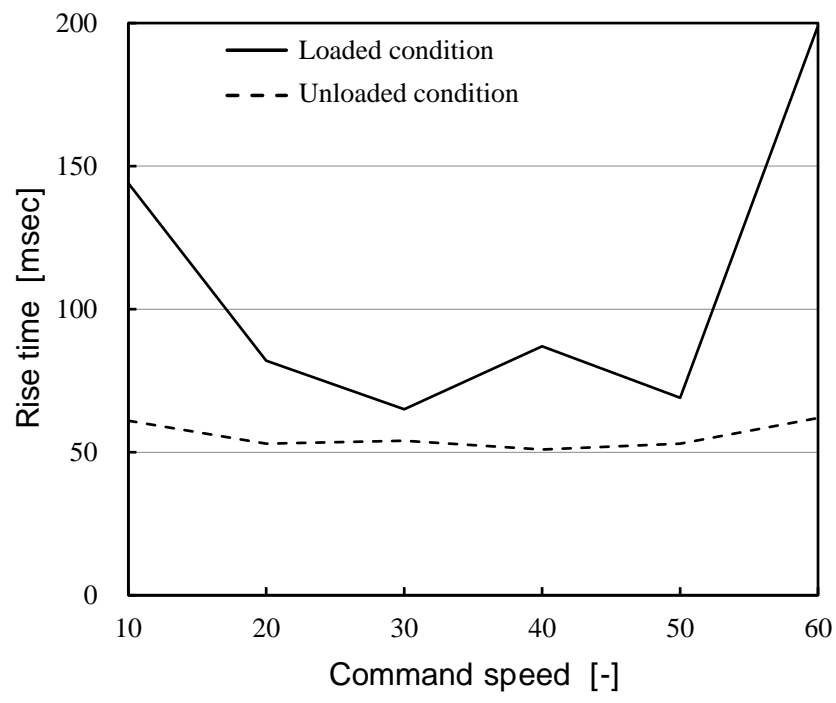

Fig. 11. Relationship between rise time and command speed in each load state.

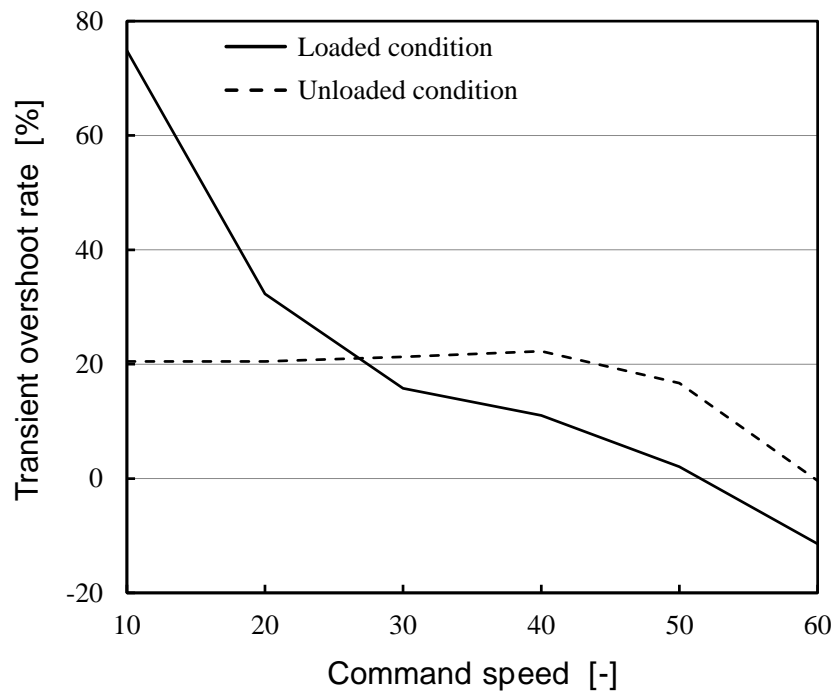

Fig. 12. Relationship between overshoot rate and command speed in each load state.
Fig. 12 に各負荷状態におけるオーバーシュート率と速 度指令の関係を示す。ここで, オーバーシュート率は, 速度指令による目標回転数と測定した最大回転数の比に よって表される。無負荷状態では, 立ち上がり時間と同 様に速度指令による傾向は確認されない。一方, 負荷状 態においては, 速度指令が高くなると単調に減少する傾 向が確認された。

以上より，無負荷状態におけるサーボシステムでは， 速度指令に対する正確な回転が確認された。また, $60 \mathrm{~kg}$ の負荷状態では, 目標回転数が極端に遅速であるとき,

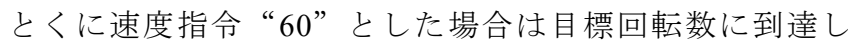
ないため，システムの正確な制御は不可能である。その ため，システムの動作範囲は速度指令 “20”（2538 rpm） 〜速度指令 “50”（6345 rpm）の間である。さらに，シス テムはこの動作範囲内において $100 \mathrm{msec}$ 以下で応答可 能であるため, 台形制御の適用により安定した動作が可 能となる。

\section{2 重心取得精度評価}

重心検知式移動機器に重心取得精度評価用荷重 $(2 \mathrm{~kg}$, $60 \mathrm{~kg}$ ) を負荷し，全方向移動システムの重心取得精度を 評価した。

Fig. 13 に各負荷荷重による誤差距離と誤差の生じた方 向を示す。縦軸は垂直軸, 横軸は水平軸を示す。ただし, 斜線部は下部にオムニホイールが位置する構造上, 正確 な測定ができない「測定不能領域」である。荷重 $2 \mathrm{~kg}$ 負 荷時では, 上側の測定点における誤差距離は大きく, 下 側は比較的小さくなった。また，すべての測定点におけ る誤差距離は $21 \mathrm{~mm}$ (円柱半径) 未満であるため, 重心 取得の誤差は小さかった。また，誤差の生じた方向は中 央後方に集中した。一方, 荷重 $60 \mathrm{~kg}$ における誤差距離 は，いくつかの交点において $21 \mathrm{~mm}$ 以上となった。とく に, 円盤の中心から遠い交点において, 誤差距離は大き い傾向となった。これは, 荷重負荷点がロードセルの設 置位置に接近すると，荷重負荷点と反対側に設置された ロードセルにおいて浮きが発生するため, 適切な荷重が 負荷されないことが一因と考えられる。

機器使用上において想定される重心領域である中央部 では誤差距離は小さいため, 許容可能な誤差距離である。 また，誤差の生じた方向は後方に集中した。これは，荷 重負荷である搭乗者の乗り方に起因するものだと考えら れる。

最大誤差距離は $60 \mathrm{~kg}$ 負荷時の測定点 $(\mathrm{X}=-1, \mathrm{Y}=2)$ に おける $49 \mathrm{~mm}$ であった。この測定点は測定不能領域に隣 接しているため，システム運用上は無視できる。また， 各測定点において誤差を含んでいるため, 測定点間距離 である $50 \mathrm{~mm}$ 未満の誤差距離は, 許容可能であると考え られる。 

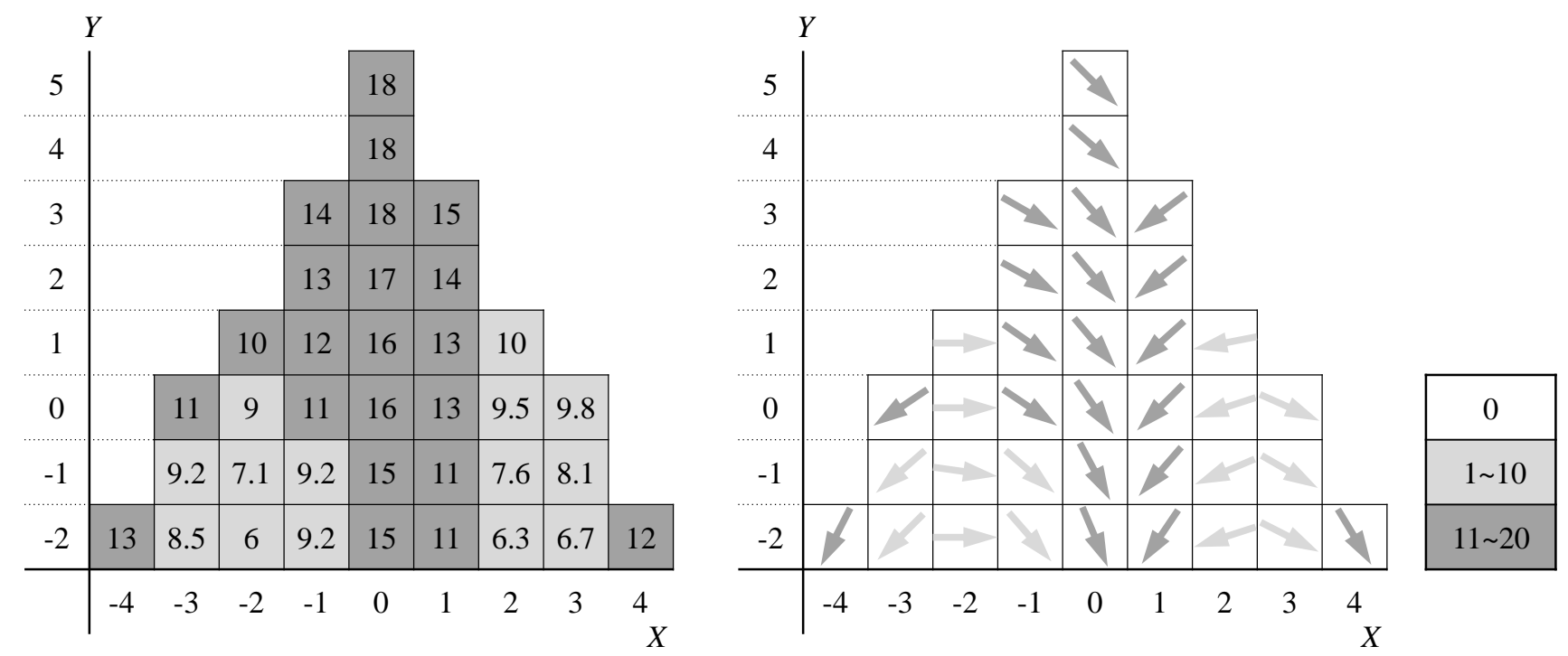

(a) $2 \mathrm{~kg}$
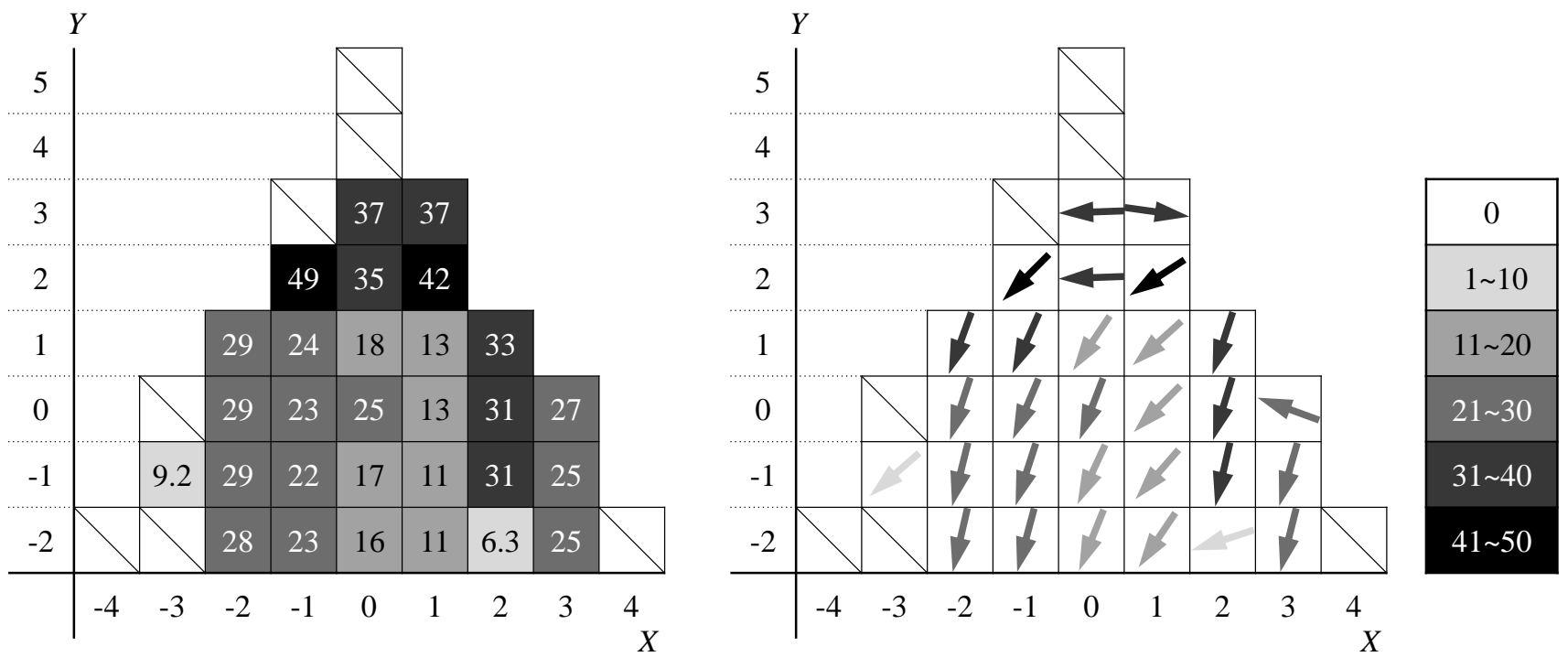

(b) $60 \mathrm{~kg}$

Fig. 13. Error distance and error direction at each load conditions.

5. 搭乗待機システム

上記実験の遂行にあたり，機器運用上の課題を観取し た.

全方向移動システムは体重移動を入力信号として扱う 特性上，重心が大きく偏る乗降動作において意図せず動 作する課題を含む。そのため，搭乗時の動作停止による 安全性確保を目的とした搭乗待機システムの実装が不可 欠である。

そこで，搭乗時の安全性確保を目的とした搭乗待機シ ステムの実装に向けた最適なシーケンス条件のうち，搭 乗待機状態の解除条件について検討した。

\section{1 システム概要}

重心検知式移動機器は, 搭乗部に搭乗した操縦者の重 心移動によって操縦される。一方, 直感的な随意操作を 可能とする特徵を有する反面, 重心が著しく変動する搭 乗動作において安全性の課題を含む。とりわけ, 機器使 用を想定している被介護者の多くは高齢者であるため, 搭乗完了までに多くの時間を要する。搭乗中の意図しな い機器駆動を抑制するには, 搭乗が完了するまで機器駆 動を停止させるシステムの導入が不可欠である。そこで, 搭乗時の安全性向上を目指して, 操縦者の搭乗完了を検 知する安全システム「搭乗待機システム」を開発した。

Fig. 14 に搭乗待機システムの動作フローを示す。ここ 


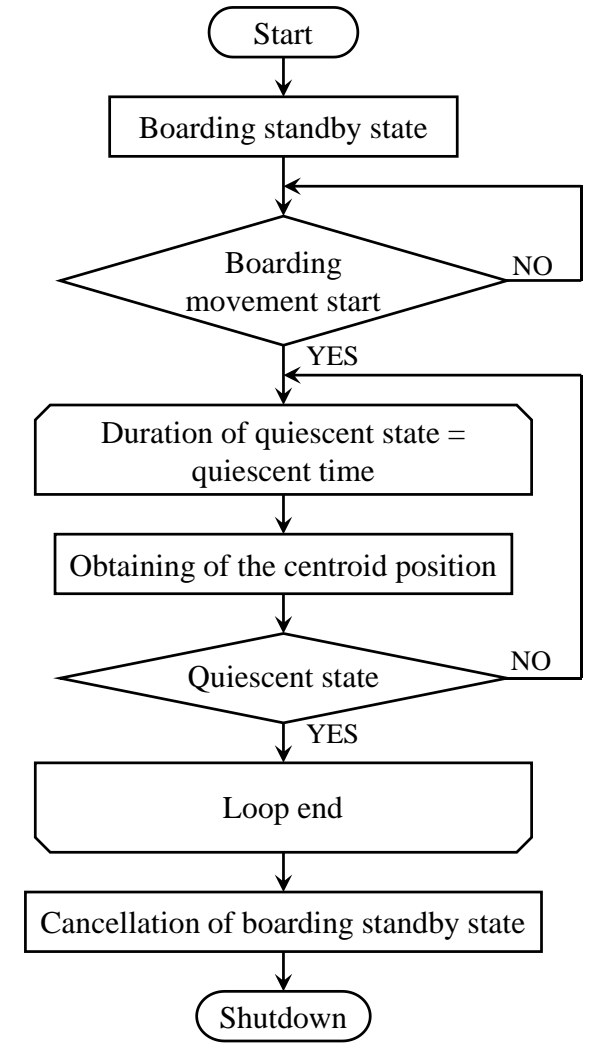

Fig. 14. Control flow of boarding standby system.

で，図中の用語を以下に定義する。

搭乗動作（Boarding movement）:

搭乗部への搭乗, 着座, 静止からなる一連の動作

静止状態（Quiescent state）:

搭乗中に重心変動が発生しない状態

静止時間（Quiescent time）:

静止状態を継続する任意に設定した時間

\section{搭乗待機状態（Boarding standby state）:}

機器駆動を停止させている状態

本システムは，搭乗中における移動機構部の駆動を停止 し, 安全な搭乗を補助する。機器はキャリブレーション 完了後に搭乗待機システムを開始し, 搭乗待機状態に移 行する。操縦者が搭乗部に搭乗すると, 重心位置算出に 基づいて重心座標を継続的に取得する。静止状態が静止 時間まで継続すると, 本システムは搭乗動作が完了した と判断し, 搭乗待機状態を解除する。本システム終了後, 機器は駆動状態へ移行する。

\section{2 実験方法}

重心検知式移動機器における搭乗時の安全性確保を目 的とした搭乗待機システムの実装に向け，搭乗待機状態 の最適な解除条件について評価し，その静止時間を検討 した。

搭乗動作における搭乗開始から着座完了（静止開始）
までを搭乗中，一定時間の静止を静止中とした。搭乗中 と静止中に各タスクを設け，搭乗中および静止中におけ る静止状態の継続時間をシステムの解除条件として設定 した。

評価項目として, 搭乗中における「搭乗タスク」と静 止中における「静止タスク」を設け, 搭乗中に静止時間 の静止状態が発生しない状態を「搭乗タスクの成功」, 静 止中に静止時間の静止状態が継続している状態を「静止 タスクの成功」と定義した。各タスクにおける静止時間 が 1〜 4 sec（1 sec 間隔）である場合のタスク成功率を評 価した。被験者の搭乗動作 (機器搭乗部への搭乗, 着座, 静止の動作）によって発生する重心変動は, 本機器と接 続した PC とのシリアル通信のログを用いて経時的に記 録した。また, 着座姿勢には安座あるいは正座を指示し, 約 $5 \mathrm{sec}$ 間の静止状態を維持させた。なお, 着座完了（静 止開始）のタイミングは被験者の申告によって判断し, ストップウォッチにて搭乗開始から申告までの経過時間 を計測した。申告直前の静止状態は, 既に静止している とみなし, 搭乗タスクには含まない。測定回数は一人あ たり 10 回とした。被験者は, 健康な学生 6 名（20.1 歳士 0.52)とし, 事前に実験の趣旨と方法について説明して十 分な理解を得た。

\section{3 実験結果}

重心検知式移動機器における搭乗待機システムの実装 に向け, 搭乗から静止に要する時間と重心変動を記録し, 搭乗タスクと静止タスクの成功率から最適な静止時間を 検討した。

Fig. 15 にタスク成功率を示す。平均搭乗タスク成功率 は，いずれの静止時間においても $80 \%$ 以上となった。と くに, 静止時間が $2 \mathrm{sec}$ 以上のとき, 静止が確認されず夕 スク成功率は $100 \%$ となった。これは, 設定する静止時 間の増加にともない，意図しない静止判定が起こらない

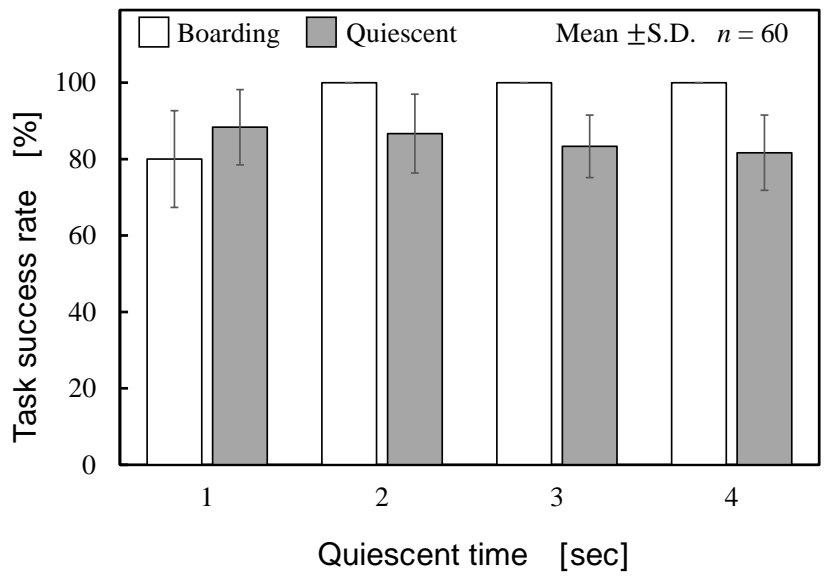

Fig. 15. Task success rate. 
ためであると考えられる。平均静止タスク成功率は, 静 止時間の増加にともなって緩やかな低下傾向を示した。

しかし，いずれの静止時間においても平均タスク成功率 は $80 \%$ 以上であった。

Fig. 16 に被験者 A，B および C における重心変動を示 す。図中の破線は被験者が着座完了（静止開始）を申告 した時間であり，左側は機器への搭乗開始から着座まで
の重心変動, 右側は着座による静止中における重心変動 を示す。各被験者とも着座後では大きな重心変動は見ら れず, 静止状態であることが確認できる。また, 被験者 $\mathrm{A}$ および被験者 $\mathrm{B}$ については, どちらも着座から約 $2 \mathrm{sec}$ 後に $x$ 軸において微小な重心変動が発生した。搭乗待機 システムは静止状態を機器駆動開始のトリガーとするた め, 誤作動防止の観点から静止時間は可能な限り長く設

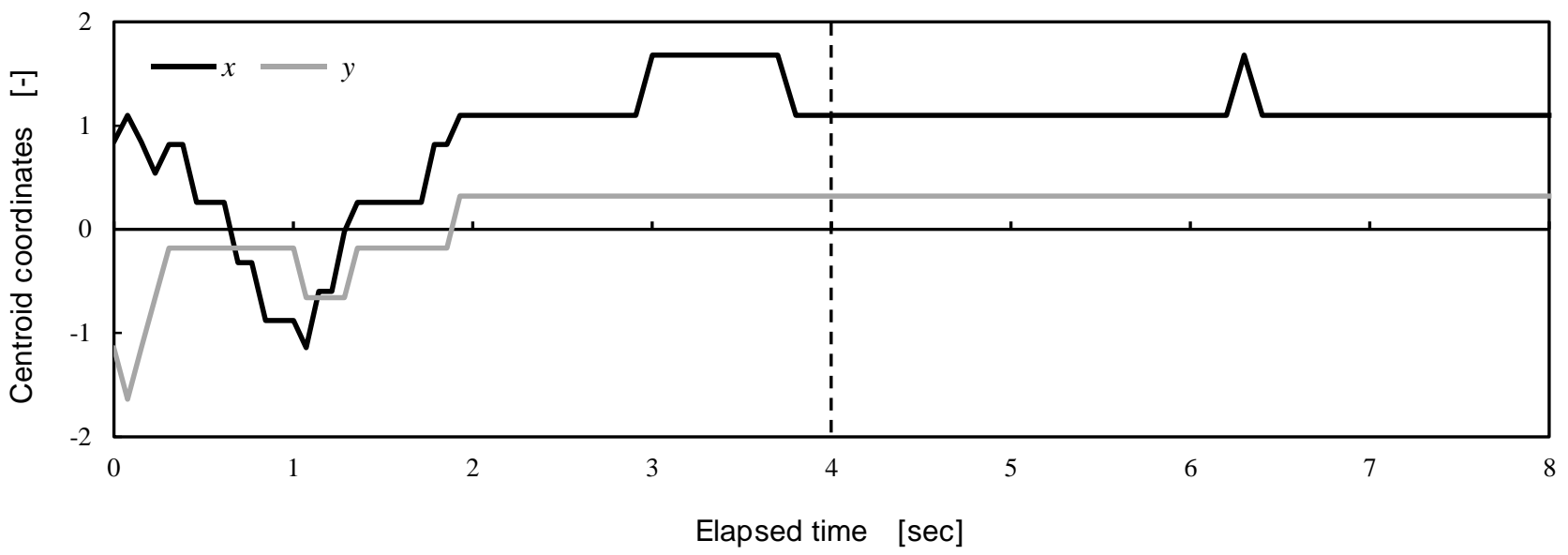

(a) Participant A

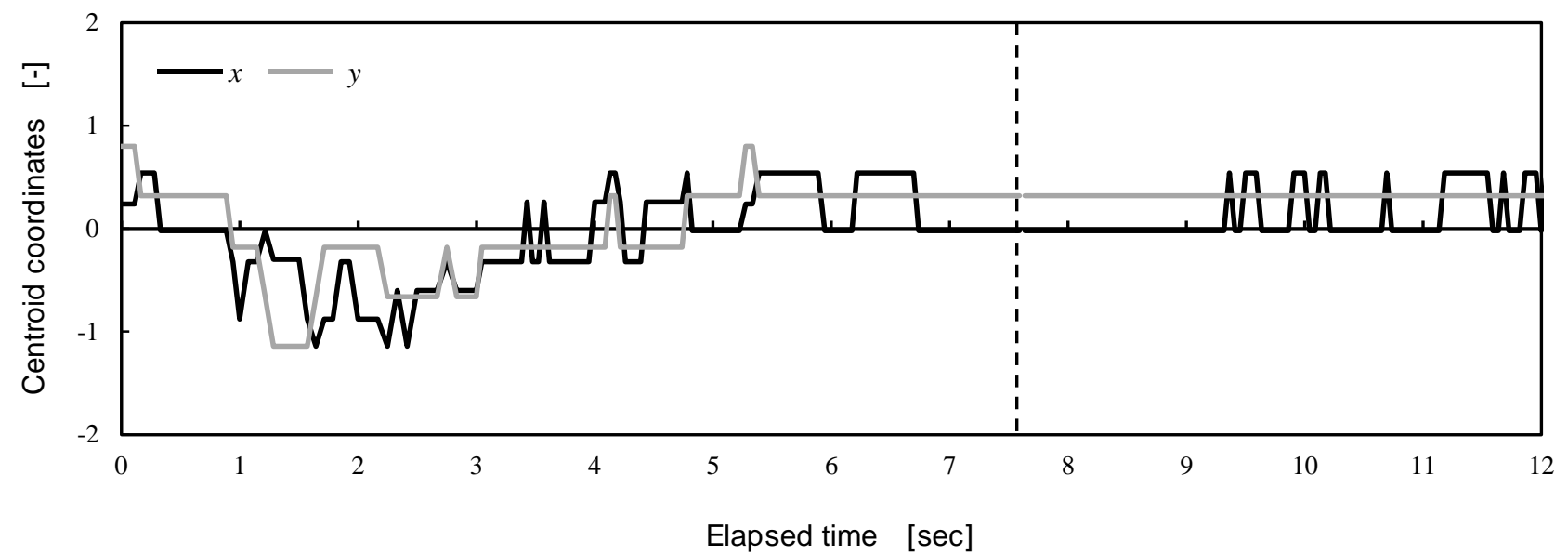

(b) Participant B

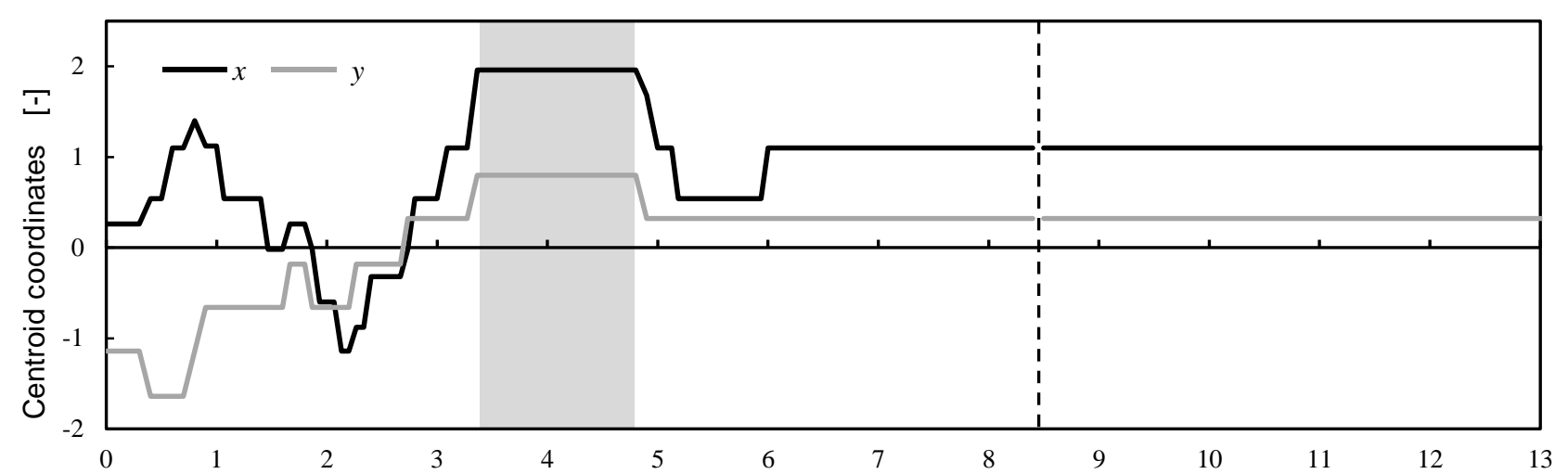

Elapsed time [sec]

(c) Participant C

Fig. 16. Centroid fluctuation 
定することが好ましい。しかしながら，被験者 $\mathrm{A} ， \mathrm{~B}$ に おいて静止中に微小な重心変動が確認されたことより,

一切の重心変動を起こさないことは困難である。そのた め, 搭乗完了を判断するためには微小な重心変動を許容 する必要があると考えられる。

被験者 $\mathrm{C}$ の搭乗中における重心変動に着目すると, 網 掛け範囲において $1 \mathrm{sec}$ 以上の静止状態が確認された。 このとき, $x$ 軸と $y$ 軸の重心位置は正側において最大と なった。これより，この静止状態は被験者が右足を乗せ て機器に搭乗し，前傾姿勢のままバランスをとるため， 一時的に静止しているタイミングにて発生したことが分 かる。したがって，静止時間を $1 \mathrm{sec}$ 以下に設定した場 合，誤動作を引き起こす可能性があるため，静止時間は 両タスクの成功率がともに高くなった $2 \mathrm{sec}$ 以上が最適 であると考えられる。また，高齢の要支援者において動 的バランスの低下が認められており (9), 搭乗から着座に 要する時間は長くなると考えられる。すなわち，高齢者 を対象とした場合，搭乗中の静止状態が頻発する可能性 が高くなるため，静止時間はさらに長く設定する必要が ある。

\section{6. 結言}

本研究では, 全方向移動システムを実装した重心検知 式移動機器の過渡応答特性と重心取得精度を評価した。 さらに，搭乗時の安全性確保を目的とした搭乗待機シス テムの実装に向けた最適なシーケンス条件のうち，搭乗 待機状態の解除条件について検討した。実験より得られ た結果の要約を以下に示す。

（1）本機器に $60 \mathrm{~kg}$ の積載物を想定した場合, サーボ システムは速度指令 “20”（2538 rpm）～速度指令 “50”(6345 rpm) の間において正確に制御可能で ある。また，この動作範囲において，台形制御の 適用により安定した動作が可能である。

（2）高負荷時における重心算出の最大誤差距離は 49 $\mathrm{mm}$ であった。しかし，これはシステムにおいて 大きな誤差でないため, 許容可能であると考えら れる。

(3) 本機器への安全な搭乗を補助する搭乗待機シス テムの静止時間は $2 \mathrm{sec}$ 以上に設定する必要があ る。また，静止中においても重心変動が発生する ため，微小な変動は許容する必要がある。

$$
\text { 文献 }
$$

（1）野川とも江：「介護福祉の QOL」, 中央法規出版, pp. 2-5 25-28, 2005

(2) 藍尚禮ほか：「日本大百科全書」，小学館

(3) 厚生労衔省：「平成 24 年度仕事と介護の両立に関する実態把握の ための調查研究事業報告書」, 2013
(4) たとえば, 厚生労働省：「平成 28 年介護サービス施設・事業所調 査の概況」, 2017

（5）たとえば, 厚生労働省:「平成 27 年介護保険事業状況報告 (年報)」, 2016

（6）橋野賢:「生活介護ロボット」, 日本ロボット学会誌, 14, 5, pp. 614618,1996

(7) 和田正義, 森俊二：「ホロノミック全方向移動ロボットの開発」, 日本ロボット学会誌，15，8，pp. 1139-1146， 1997

（8）大越健介, 道信剛志, 重原淳孝：「二次電池とエネルギー問題 特 にリチウムイオンバッテリーを中心として」, 化学と教育, 56, 3, pp. 110-113, 2008

（9）長澤伸江, 古田なつみ, 諏訪部早紀, 仲澤槙子, 平林美輝, 松本晃 裕, 池川繁樹:「介護予防教室参加者の身体機能の検討一要介護移 行防止の視点から要介護認定者との比較—」, Bulletin of Jumonji University, vol.46, pp.117-126, (2015)

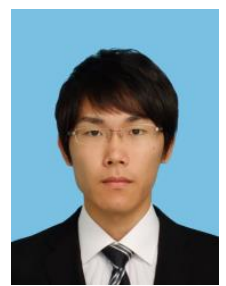

田中陽平

2017 年 3 月鶴岡工業高等専門学校 制御情報工 学科卒業。同年 4 月鶴岡工業高等専門学校 生産シ ステム工学専攻入学 機械・制御コース, 現在に至 る。多孔質材料の力学解析に従事。

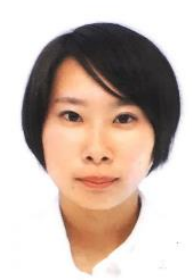

阿部 あすか

2018 年 3 月鶴岡工業高等専門学校 制御情報工 学科卒業。同年 4 月本田技研工業株式会社入社, 現在に至る。

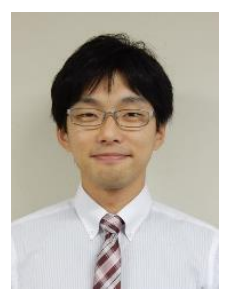

田村 和輝

2019 年 3 月千葉大学大学院工学研究科博士後期 課程修了。2018 年 3 月より浜松医科大学 光尖端医 学教育センター 助教, 現在に至る。超音波医用計 測の研究に従事。IEEE, 日本音響学会, 日本超音 波医学会会員。工学博士

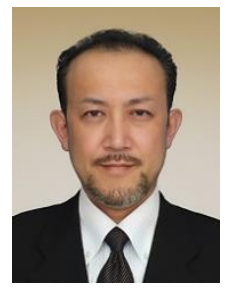

宾戸 道明

2008 年 3 月山形大学大学院理工学研究科博士後 期課程修了。同年 4 月鶴岡工業高等専門学校助教, 2016 年 4 月教授, 現在に至る。エンジニアリング デザイン関連研究に従事。技術士 (機械部門・総合 技術監理部門） 